\title{
Macro and microscopic characters of Maerua oblongifolia (Forssk.) A. Rich leaf
}

\author{
G. Prabhakar*,K. Shailaja, and P.Kamalakar \\ Plant Physiology and Biochemistry Laboratory, Department of Botany, Osmania University, Hyderabad -500007, \\ Telangana, India
}

Received: September 09, 2019 Revised: October 23, 2020 Accepted: October 31, 2020 Published: November 23, 2020

\section{*Correspondence author:} G. Prabhakar, E-mail:gajulaprabhakar@gmail. com

\section{ABSTRACT}

The paper deals with a detailed investigation on the leaves of Maerua oblongifolia (Forssk.) A. Rich. which includes it's morphological, anatomical and powder analysis. It is a low woody bushy under-shrub belonging to the family Capparaceae. The leaves are used in treatment of as fever, ear ache, stomach ache, skin infections, urinary calculii, diabetes mellitus, epilepsy, rigidity in lower limbs, and abdominal colic. The leaf amphistomatic, with mostly anamocytic, few tetracytic stomata. In transverse section of leaf is ribbed on either sides at midvein, epidermis one layered. Mesophyll differentiated into palisade and spongy tissues. Ground tissue of midvein differentiated into palisade, collenchyma and parenchyma. The midvien consists of one large oval shaped vascular bundles arranged are at the centre. Petiole in transverse section is circular adaxially small, grooved at centre and epidermis is having one layered, a single circular vascular bundle present at the centre, vascular bundle is enclosed by endodermis. The powder microscopic and organoleptic characters are also presented in this study. This study would helps as an appropriate source for authentification of the present studied drug.

KEYWORDS: Maerua oblongifolia, Capparaceae, powder analysis, organoleptic characters, macro- micro studies

\section{INTRODUCTION}

Maerua oblongifolia (Forssk.) A. Rich. (syn. Maerua arenaria, Niebhuria arenaria), commnoly known as "Bhoochakra Gadda." in Telugu, 'Hemkand' in Hindi and 'Bhumichakkarai' in Tamil, belongs to the family Capparaceae. It is a low woody bushy under-shrub up to $4 \mathrm{~m}$ long, branches glabrous, found in Indian subcontinent and Srilanka [1]. The leaves are simple, ovate, elliptic-oblong or lanceolate, $3-4.5 \times 2.3 \mathrm{~cm}$, scabrous, margin entire, base and apex obtuse, apex mucronate; petiole to $1 \mathrm{~cm}$ long. Racemes corymbose, $5-10 \mathrm{~cm}$; peduncle to $3 \mathrm{~cm}$; pedicel to $2 \mathrm{~cm}$. Flowers $1.5 \mathrm{~cm}$ across, greenish- yellow in corymbs, rarely flowers solitary, axillary, mildly fragrant; bracts small, ovate; sepals 4, petaloid, united near base or up to one- third from base, calyxtube 3-8 $\mathrm{mm}$ long, lined by a tubular truncate disc, lobes ellipticoblong; petals 4, on cup-shaped disc, ovate-lanceolate to obovate; stamens 20-26; filaments subulate, to $2 \mathrm{~cm}$, greenish or white, brownish or purple on drying ; anthers oblong, $4 \mathrm{~mm}$. Androphore equal to receptacle. Gynophores $1.5-2.5 \mathrm{~cm}$ long; ovary ovoid, $7 \mathrm{~mm}$ cylindrical, stigma sessile. Berry moniliform, fleshy, to $12 \times 2 \mathrm{~cm}$, elongate, twisted and deeply constricted between the seeds; seeds globose , $7 \times 5 \mathrm{~mm}$, minutely echinate-tuberculate. Flower \& Fruit: January to June [2-5]. (Figure la, b\&c). The roots are used tonic and stimulant [6]. Micropropagation a liana of arid areas [7]. Pharmacognostical studies on the roots [8]. Evaluation of antipyretic activity of root extracts[9] Effect on alloxan induced diabetes in rats [10], a lupine triterpenoid [11], Hepatoprotective Activity of Ethanol and Aqueous Extract [12], In vitro antimicrobial activity and cytotoxicity [13], The roots are used to energy stimulant [14], The root bulb are given to cure diabetes [15], The leaves and bark anti emetic [16], The leaves are used rheumatism [17], The roots are used as aphrodisiac [18]. The tubers are used in fertility [19], Extraction, isolation and characterization [20], anti malaria, Insecticidal and Repellent Properties [21]. The root s are used Evil eye/luck [22], the roots are used to antiperiodic, diuretic, purgative, dropsy, urinary disorders, febrifuge, stomachic and diabetes [23], nithya pooja kona sacred groove [24]. Micro propagation [25], whole plant is fed as fodder to increase lactation [26]. In the present investigation the leaves are used to ethno medicinally, curing the fever.

\section{MATERIALS AND METHODS}

Maerua oblongifolia.(Forssk.) A.Rich. was collected in the flowering and fruiting stage from Osmania University campus, Hyderabad Telangana state, India. Collected material was poisoned and mounted on herbarium sheets, taxonomically

Copyright: () The authors. This article is open access and licensed under the terms of the Creative Commons Attribution License (http://creativecommons.org/licenses/by/4.0/) which permits unrestricted, use, distribution and reproduction in any medium, or format for any purpose, even commercially provided the work is properly cited. Attribution - You must give appropriate credit, provide a link to the license, and indicate if changes were made. 


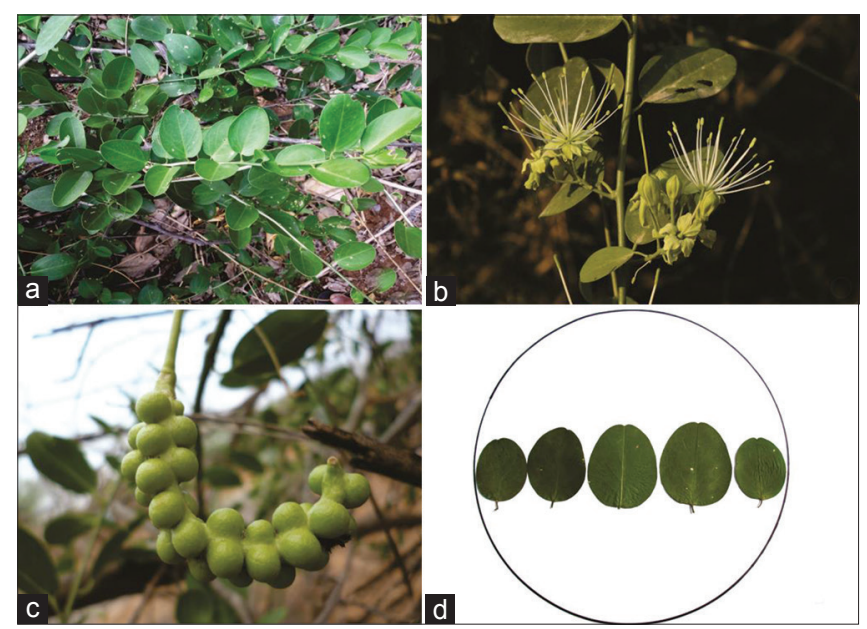

Figure 1: a-c Flowering and fruiting twig of $M$. oblongifolia; ' $d$ '-Leaf macroscopy

identified by the Botanical Survey of India (BSI) Deccan regional centre Hyderabad and deposited in Herbarium, Botany Department, Osmania University, Hyderabad, Telangna (HY).The leaves were boiled, fixed in F:A:A. (Formaldehyde : Acetic acid : Alcohol), dehydrated through xylene - alcohol series and embedded in paraffin wax. The sections were cut at $10-12 \mu \mathrm{m}$ on Optica 1090A rotary microtome, stained with Crystal violet and basicfuchsin combination and mounted in canadabalsam method by Johansen [27]. Epidermal peels were obtained by gently scraping and peeling by razor blade, double treatments were done following the methods of Leelavathi, and Ramayya [28]. Peels were stained with saffranine and mounted in glycerin. The powder microscopy characters were studied by boiling the drug in distilled water, stained in saffranine and mounting with glycerine. The photomicrography was done on Olympus BX53 research trinocular microscope, attached with digital Sony camera.

\section{OBSERVATIONS AND RESULTS}

\section{Macroscopic Characters}

The Leaves are simple, ovate, elliptic-oblong or lanceolate, $3-4.5 \times 2.3 \mathrm{~cm}$, scabrous, margin entire, base and apex obtuse, apex mucronate; petiole to $1 \mathrm{~cm}$ long. Racemes corymbose, 5-10 cm; peduncle to $3 \mathrm{~cm}$; pedicel to $2 \mathrm{~cm}$. (Figure ld).

\section{Microscopic Characters}

In leaf surface view, adaxial epidermal cells mostly 5-7 sided, few up to 8 sided, polygonal anisodiametric, few isodiametric, sides thick, straight to curved, surface striated contents dense. Distribution of epidermal cells common, all over, except on veins, irregularly arranged variously oriented. Costal cells 5-7 sided, mostly polygonal to linear, anisodiametric, sides straight to curved, surface striated, contents dense in few. Distributed on primary and secondary veins, irregularly arranged, parallelly oriented. Stomata are present in both sides which are anomocytic, few tetracytic. Subsidiaries 4, indistinct, monocyclic, mostly of f-type, few a-type; guard cells reniform, densely cytoplasmic. Except subsidiaries mostly of c-type, few a-type in abaxiaaly Distribution of subsidiaries common, all over, except on veins, irregularly arranged, variously oriented. Epidermal cell frequency 2056 per sq. $\mathrm{mm}^{2}$, stomatal frequency 50 per sq. $\mathrm{mm}^{2}$, and stomatal index 2.51 .

\section{Leaf Lamina Abaxial}

The abaxial surface studies are similar to the adaxial surface studies, the stomatal complex studies similar to adaxial but except on subsidiaries mostly of c-type, few a-type. The abaxial surface epidermal cell frequency 1762 per sq.mm. stomatal frequency 640 per sq.mm., and stomatal index 27.1 (Figure 2a-f).

\section{Transverse Section of Leaf}

In T.S. of leaf is ribbed on either sides at midvein; secondary veins also ribbed; lamina wings $112-151(130) \mu \mathrm{m}$ and midvein 626-756(677) $\mu \mathrm{m}$ in thickness. Epidermis one layered, often with elevated trichome bases; cells mostly barrel shaped and ova to circular; adaxially larger, elongated cells 19-49(32) $\mu \mathrm{m}$ long, 14$27(21) \mu \mathrm{m}$ wide and isodiametric cells1 1-25(17) $\mu \mathrm{m}$ in diameter; abaxially smaller, narrower 11-27(18) $\mu \mathrm{m}$ in long and 5-16(11) $\mu \mathrm{m}$ wide and isodiametric cells 5-14(9) $\mu \mathrm{m}$ in diameter, contents scanty; covered by thin cuticle. Cells over on midvein mostly barrel shaped and ova to circular, 25-50(35) $\mu \mathrm{m}$ long, 15-20(18) $\mu \mathrm{m}$ wide and isodiametric cells $13-25$ (18) $\mu \mathrm{m}$ in diameter, adaxially; abaxially barrel shaped and ova to circular, 15-35-(25) $\mu \mathrm{m}$ long, 10-25(17) $\mu \mathrm{m}$ wide and isodiametric cells 8-23(15) $\mu \mathrm{m}$ in diameter, walls thick, contents scanty, cuticle slightly thick on either sides (Figure 3a).

Mesophyll dorsiventral, heterogenous differentiated into palisade and spongy tissues. Palisade 1-2 layered, throughout, extending into midvien and secondary veins cells cylindrical, columnar, with large intercellular spaces 27-55(41) $\mu \mathrm{m}$ long and 8-22(15) $\mu \mathrm{m}$ wide, walls thick and interspersed with sphaerocrystals in few; contents dense with chloroplasts. Spongy tissue 3-5 celled, cells mostly oval to oblong, few dumbbell shaped 14$30(22) \mu \mathrm{m}$ in diameter, loosely arranged with large intercellular spaces, interrupted by sphaerocrystalliferous idioblasts, contents dense with chloroplasts ( Figure 3b).

Ground tissue of midvein heterogenous, differentiated into palisade, collenchyma and parenchyma. Collenchyma 3-4 layered on adaxial side, l-layered on abaxial lamellar, cells polygonal, circular, larger in size 11-22(17) $\mu \mathrm{m}$ in diameter on adaxial; smaller, polygonal to spherical 8-19(13) $\mu \mathrm{m}$ on abaxial, intercellular spaces absent, walls thick, contents scanty. Palisade 1-2 layered beneath the collenchyma on adaxial described in mesophyll. Parenchyma 3-4 layered an adaxial and 3-6 layered on abaxial cells polygonal oaval to circular 25-55(36) $\mu \mathrm{m}$ in diameter adaxially and 33-82(46) $\mu \mathrm{m}$ in diameter on abaxial, without inter cellular spaces, interspersed with sphaerocrystals in few, contents slightly dense in few (Figure 3a).

Vascular tissue of midvien consists of one large oval shaped vascular bundles arranged are at the centre; about 108216(152) $\mu \mathrm{m}$ in diameter, conjoint, collateral, endarch; xylem 

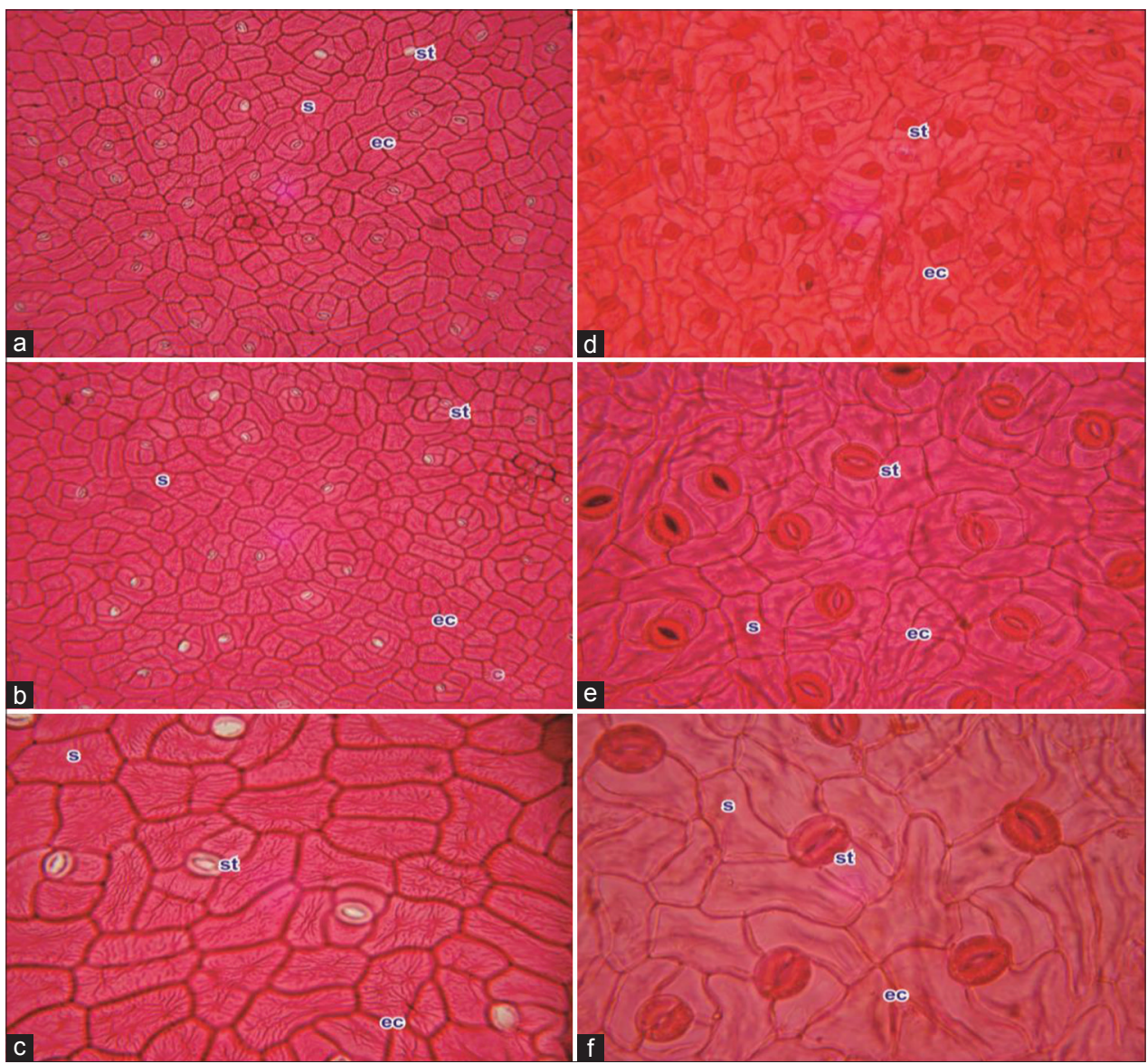

Figure 2:'a'-Leaf adaxial surface with epidermal cells X 185;'b'-Leaf adaxial surface with epidermal cells and striations X 185; 'c'-Leaf adaxial surface with stomata X 380;'d'-Leaf abaxial surface with epidermal cells X 195;'e'-Leaf abaxial surface with stomata X 345;'f'-Leaf abaxial surface with stomata andstriations $X 350$

consists of trachieds, vessels, fibers and tracheary elements arranged as cluster, interrupted by xylem parenchyma; tracheary elements 50-70 in number in the midvein, polygonal, circular, lignified, about 8-20(13) $\mu \mathrm{m}$ in diameter, in L.S. they show annular, helical thickenings. Phloem scanty, on ventral side, with phloem parenchyma, sieve tubes and sieve cells accompanied with companion cells. Phloem parenchyma compactly arranged without intercellular spaces, contents scanty (Figure 3a).

\section{TRANSVERSE SECTION OF PETIOLE}

In T.S. of petiole is circular adaxially small, grooved at centre $572-1243(901) \mu \mathrm{m}$ in diameter epidermis one layered cells mostly oval to circular 15-40 (28) $\mu \mathrm{m}$ in diameter, covered by thick cuticle, contents slightly dense. Ground tissue heterogeneous consisting of collenchyma and parenchyma tissues. Collenchyma hypodermal, 2-3 layered, throughout, cells polygonal, oval to circular, lamellar 13-35(25) $\mu \mathrm{m}$ in diameter; contents slightly dense. Parenchyma Abundant, occupied rest of the ground tissue, cells polygonal, mostly circular, few oval shaped, closely packed with small intercellular spaces 25 50(37) $\mu \mathrm{m}$ in diameter, contents slightly dense.

Vascular tissue consists of a single circular vascular bundle present at the centre. Vascular bundle is enclosed by endodermis, 322-506(430) $\mu \mathrm{m}$ in diameter, xylem consisting of tracheary elements 8-18(25) $\mu \mathrm{m}$ in diameter; arranged in radial rows, interrupted by xylem parenchyma, phloem is scanty, surrounding the xylem. Phloem consists phloem parenchyma, sieve tube and sieve cells accompanied with companion cells. A small amount of pith present at the centre of vascular bundle, in longitudinal section tracheary elements show annular and helical thickenings. (Figure 3c).

\section{Powder Microscopy}

Fragments of epidermal cells with straight to curved sides; pieces of epidermis with anamocytic stomata; powder consists of epidermal cells with tetracytic stomata; fragments of costal cells with linear walls; isolated fragments of rhamboidal crystals; broken fragments of epidermal cells; epidermal cells with straitions; Tracheary elements with helical thickenings (Figure $4 \mathrm{a}-\mathrm{h}$ ).

\section{Organoleptic Characters}

Colour: Dark green; Touch: smooth; Odour: No characteristic Taste: No characteristic. 


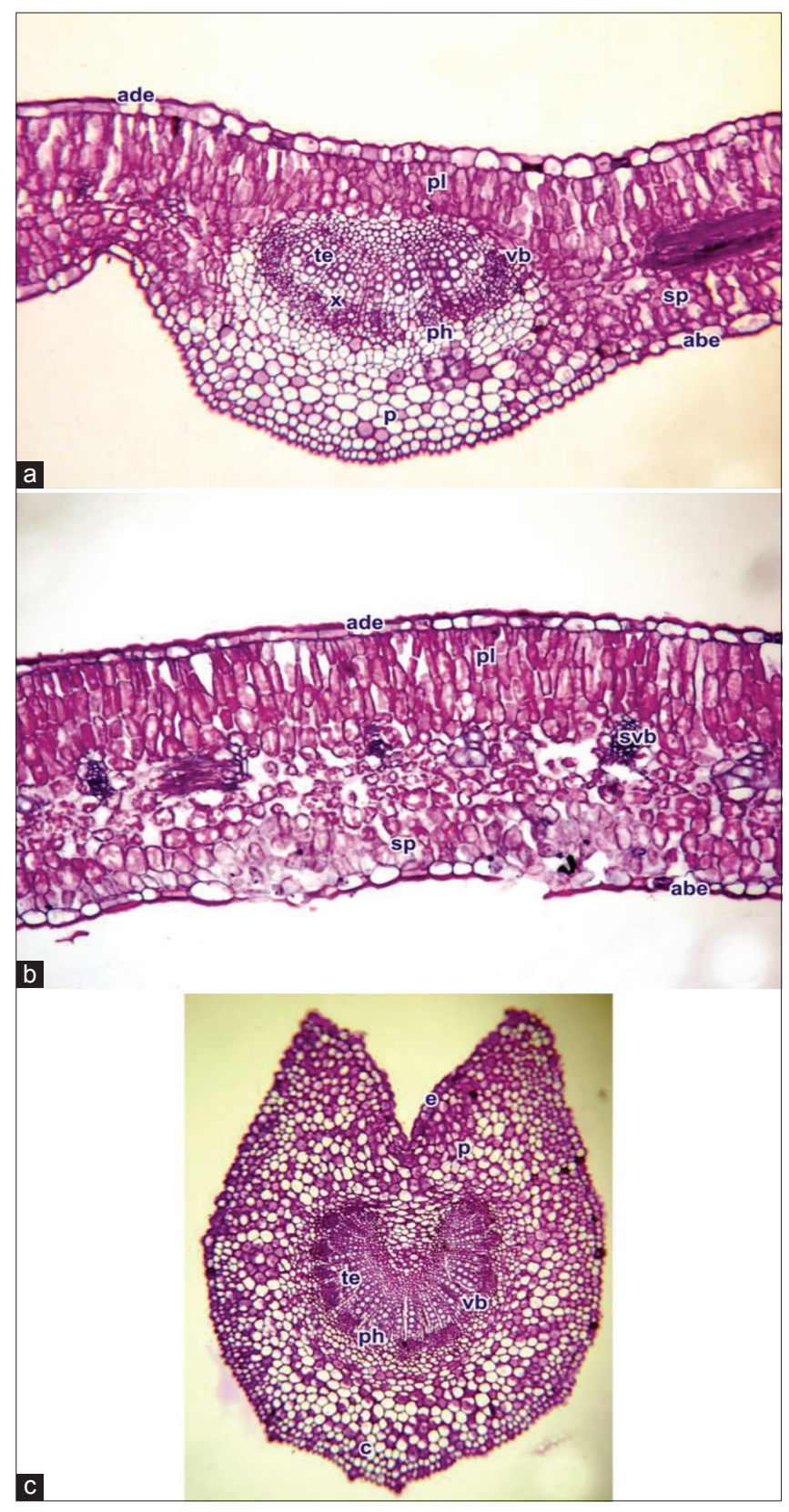

Figure 3: 'a'. T.S. of Leaf midvein X 155; 'b' T.S. of Leaf lamina X 145; 'c' T.S. of Petiole X 132

Abbreviations: e- epidermis; ade- adaxial epidermis; abe- abaxial epidermis; pl- palisade; sp- spongy tissue; c- collenchyma; p-parenchyma; vb- vascular bundle; svb- secondary vascular bundle; ph-phloem; x-xylem;- st- stomata; ec- epidermalcells; s-striations; ts- transversesection.

\section{DISCUSSION}

There were no reports to regards Maerua oblongifolia leaves, this was the first report with regard to macro and microscopic characters of leaf of maerua oblongifolia. Locally the plant is popular known as "Bhoochakara Gadda". A combination of characters such as epidermal cell size, their distribution, stomatal index, presence or absence of hairs, their types, palisade

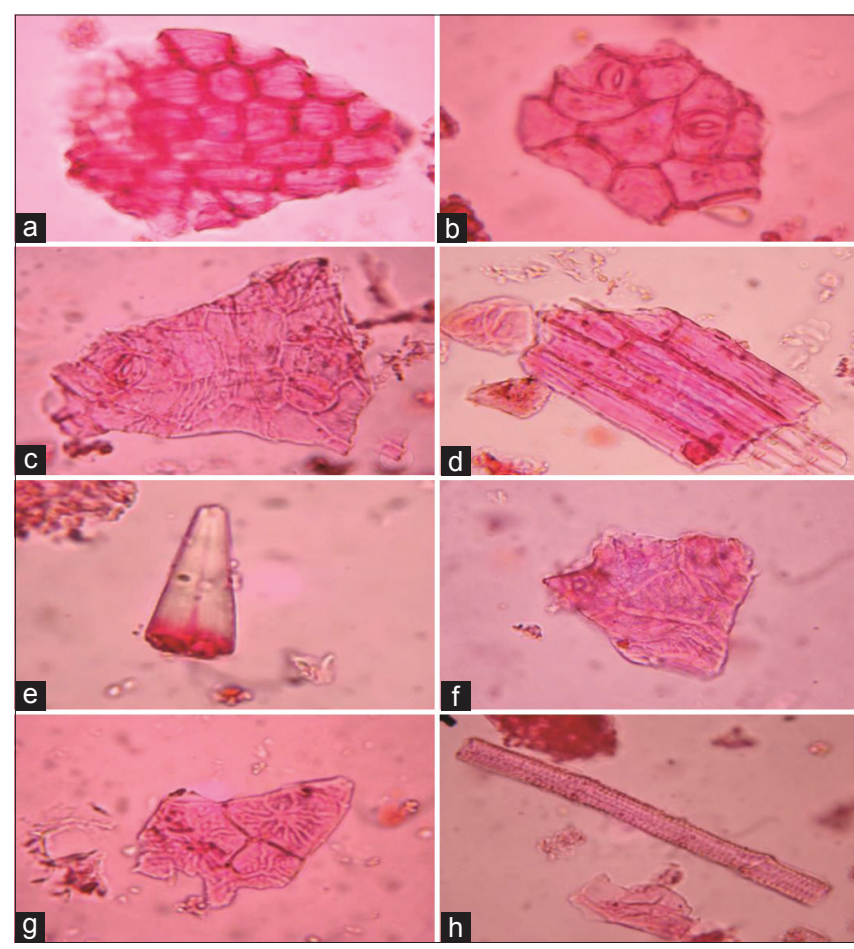

Figure 4: Powder microscopy images of $M$. oblongifolia a-h

ratio, venation pattern, vein-islet number, vein let termination number are found to be very significant micro-morphological characters in the identification of crude drugs [29,30]. Surface view the epidermal cells are mostly 5-7 sided, few up to 8 sided, polygonal anisodiametric, few isodiametric, sides thick, straight to curved, surface striated, contents dense either surfaces. The epidermal cells on the Adaxial are more frequent on adaxial being 2056 per sq. $\mathrm{mm}^{2}$, compared to the abaxial surface with 1762 per sq. $\mathrm{mm}^{2}$. The costal cells are 5-7 sided, mostly polygonal to linear, anisodiametric, sides straight to curved, surface striated, contents dense in few. Metcalfe and chalk [31] reported that the very few characters are constant throughout the family. The stomata are amphistomatic with anomocytic stomata. The present study confirms the above observation but reports the occurrence of few tetracytic stomata on both sides which is a new information with subsidiaries indistinct of monocyclic, mostly of f-type, few a-type; guard cells reniform, except subsidiaries while mostly of c-type, few a-type on abaxial side. In leaf transection the midvein is ribbed on either sides at midvein; secondary veins also ribbed. Lamina is dorsiventral Palisade 1-2 layered, throughout, extending into midvien and secondary veins. Spongy tissue 3-5 celled, cells mostly oval to oblong, few dumbbell shaped, interrupted by sphaerocrystalliferous idioblasts presently confirmed. Ground tissue of midvein differentiated into palisade, collenchyma and parenchyma. Collenchyma 3-4 layered on adaxial side, 1-layered on abaxial side confirmed. Palisade 1-2 layered beneath the collenchyma. Parenchyma 3-4 layered an adaxial and 3-6 layered on abaxial presently observed. Metcalfe and chalk [31] reported some capparis genus midrib usually with vascular bundles arranged in a straight band or in an arc with the convex surface towards the lower side. Presently vascular tissue of midvien consists of one large oval shaped vascular bundles arranged are at the 
centre, vascular bundle is conjoint, collateral, endarch. In T.S. of petiole, circular adaxially are small, grooved at centre. Ground tissue consisting of collenchyma and parenchyma tissues. Collenchyma 2-3 layered, parenchyma abundant, occupied rest of the ground tissue presently observed. Vascular tissue consists of a single circular vascular bundle present at the centre.

\section{CONCLUSION}

The macro and microscopic features and organoleptic characters along with the anatomical studies are diagnostic and establish in the standards for the plant leaf drug.

\section{ACKNOWLEDGMENT}

The authors are thankful to the Head, Department of Botany, Osmania University, Hyderabad for providing facilities. The authors thankful to UGC for providing financial assist ants RFSMS-BSR Fellowship. Dr. P. Uday Kumar, Deputy Director, Pathology Division, National Institute of Nutrition, Hyderabad for the microtome facility.

\section{REFERENCES}

1. Matthew K.M. Flora Tamilnadu Carnatic. 1981; 3:39.

2. Gamble JS. Flora of Presidency of Madras B.S.I. Calcutta. 1915; 1:42.

3. Pullaiah T. Flora of Telangana the $29^{\text {th }}$ state of India.2015; $1: 81$.

4. Reddy KN \& Sudhakar Reddy. Flora of Telangana. 2016; 58.

5. Hook $f \&$ Thomson. Flora of British India.1872; 1:171.

6. Kanny Lall Dey and Rai Bahadur. The indigenous drugs of India. Pama Primlane the Chronica Botanica, New Delhi, India.1973; 2:179.

7. Rathore, JS. Shekhawat NS. \& Rathore MS. Microprapagation of Maerua oblongifolia- A liana of arid areas. Phytomorphology. 2005; 55: 241-247.

8. Madhavan V, Munisamy U, Yoganarasimhan S, Gurudeva M, Rajamanickam D, Saravanan S, and Mythreyi R. Pharmacognostical studies on the roots of Maerua oblongifolia (Forsk.)A.Rich. (Capparaceae). Asian Journal of Traditional Medicines. 2012; 7(1): 29-38.

9. Arulanandraj N, Punithavani T, Indumathy S. Evaluation of antipyretic activity of root extracts of murva (Maerua oblongifolia) in rats. International Journal of Universal Pharmacy and Life Sciences. 2011a; 1(2): 1-8.

10. Arulanandraj N, Punithavani T, Indumathy S. Effect of Murva (Maerua oblongifolia) on alloxan induced diabetes in rats. International journal of pharmaceutical sciences and research 2011b; 2(10): 2754-2756.

11. Abdel-Mogib M. A lupine triterpenoid from Maerua oblongifolia. Phytochemistry. 1999; 51: 44- 48.

12. Saravanan S. Hepatoprotective activity of ethanol and aqueous extract of Maerua Oblongifolia (Forsk) a Rich (Capparaceae). Root - A Botanical Source for Ayurveda Drug, Murva, $8^{\text {th }}$ Asian Association of Schools of Pharmacy Conference, Mysore. 2017.

13. Moglad EHO, Abdalla OM, Abd Algadir H, Koko WS and Saadabi AM.
In vitro antimicrobial activity and cytotoxicity of Maerua oblongifolia. Int J Med Med Sci. 2014; 1 (3):32-37.

14. Savithramma N, Yugandhar P, Siva Prasad K, Ankanna S, Madhava Chetty K. Ethnomedicinal studies on plants used by yanadi tribe of Chandragiri reserve forest area, Chittoor District, Andhra Pradesh, India. Journal of Intercultural Ethno pharmacology. 2016; 5 (1): 49-56.

15. Ratna raju P, Yugandhar and Savithramma N. Documentation of ethno medicinal knowledge of hilly tract areas of East Godavari district of Andhra Pradesh, India. International Journal of Pharmacy and Pharmaceutical Sciences. 2014; Vol .6(4):369-374.

16. Srinivas Rao S, Medicinal flora of Sri Parvathi Jadala Rama Lingeshwara Swamy sacred grove, Nalgonda District, Telangana. Journal of Medicinal Plants Studies. 2016; 4(1):39-46.

17. Sudhakar Reddy C, Reddy K.N, Tulasi Rao K, and Pattanaik C. Ethnobotanical studies on medicinal plants used by the chenchus of Nallamalais in Kurnool District, Andhra Pradesh, India. Research journal of Medicinal Plant. 2007; 1(4):128-133.

18. Shali Saheb T. A Study on Medicinal Climbers of Nallamalais, Andhra Pradesh. International Journal of Multidisciplinary Research and Development. 2014; 1(5): 172-176.

19. Sreeramulu N, Sateesh S, Ragan A and Raju V.S. Ethno-botanicomedicine for common human ailments in Nalgonda and Waranga Districts of Telangana, Andhra Pradesh, India. Annals of Plant Sciences. 2013; 02 (07): 220-229.

20. Desta E, Mebratu L, Alemu L and Mathewos A. Extraction, isolation and characterization of Maerua oblongifolia. International Journal of Current Research in Biosciences and Plant Biology. 2018; 5(3):42-48.

21. Misganaw $M \&$ Zemede $A$. Review of antimalarial, pesticidal and repellent Plants in the Ethiopian Traditional Herbal Medicine. Research \& Reviews: Journal of Herbal Science. 2015; 3 (3):21 -45.

22. Tahani Osman I, Mohamed S, Sakina Y.R, Ahmed H, Najeeb T.M Mohamed $\mathrm{M}$ and Osman Khider T. Ethnobotanical investigation on Medicinal plants in Algoz area (South Kordofan), Sudan. Journal of Ethno biology and Ethno medicine. 2018; 14:31.

23. Madhava Chetty K, Sivaji K and Tulasi Rao K. Flowering Plants of Chittoor District-Andhra Pradesh, India.1 edn. Students offset printers, Tirupati. 2008; $14-25$.

24. Basha, S.K.M, John Paul M and Siva Kumar Reddy P. Phytodiversity and conservation of nithya pooja kona sacred grove of Nallamala hill range, Eastern Ghats, Andhra Pradesh. International Journal of Environment.2015; 4(2):271-288.

25. Mahender Singh R and Narpat Singh S. Micro propagation of Maerua oblongifolia. A rare ornamental from semi arid regions of Rajasthan, India. Journal of Developmental Biology and Tissue Engineering. 2011;3(8): 92-98

26. Nisha M, Silori CS, Gupta L and Dixit A.M. Indigenous knowledge on animal health care practices in district Kachchh, Gujarat. Indian journal of traditional knowledge. 2003; 2 (3): 240-254.

27. Johansen DA. Plant Micro technique. Mc. Graw Hill, Book Co., New York; 1940

28. Leelavathi P and Ramayya N. Rapid isolation of leaf epidermis by double treatment method. Geobios. 1975; 2: 117-119. Krishanamurthy K.HE Sundaram R. Foliar epidermis and pharmacognosy in some members in Asclepiadaceae. The Indian Botanical Society. 1967; 40:160-168.

29. Krishanamurthy K.H \& Kannabiran B. Histomorphology of foliar epidermis and pharmacognosy in some members in Asclepiadaceae. The Indian Botanical Society .1970; 49:105-113.

30. Metcalfe C.R and Chalk. Anatomy of the Dicotyledons, Vol. I \& II, Clarendon press, Oxford.1950. 